\title{
Impact of Stakeholders on Implementation of Strategic Plans in Tanzania's Public Sector
}

\author{
Venance Shillingi Salum \\ PhD Candidate, Jomo Kenyatta University of Agriculture and Technology (JKUAT), \\ Nairobi, Kenya
}

Prof. Roselyn. W. Gakure

Professor, Jomo Kenyatta University of Agriculture and Technology (JKUAT), Nairobi, Kenya

Prof. Romanus Othiambo

Professor, Jomo Kenyatta University of Agriculture and Technology (JKUAT), Nairobi, Kenya

Received: Dec. 8, 2017 Accepted: Dec. 25, 2017 Online published: Dec. 27, 2017

doi:10.5296/jpag.v7i4.12255 URL: https://doi.org/10.5296/jpag.v7i4.12255

\begin{abstract}
The study investigated the impact of stakeholders on implementation of strategic plans in Tanzania's public sector. Organisations fail not due to bad formulation of strategies, but the execution of strategies is vital to their failure or demise; and hence implementation process remains a challenge towards achieving organisation objectives. The main objective of the study was to investigate the impact of stakeholders on implementation of Strategic Plans in public sector. Seven (7) executive agencies which made $26 \%$ of all 27 executive agencies in Tanzania were randomly drawn using simple random sampling. Then, stratified random sampling was used to obtain a sample size of one hundred eighty-eight (188) respondents which was $30 \%$ of the target populations (632 employees) in the headquarters of sampled executive agencies. The study found that there was weak positive relationship $(R=0.236)$ between role of stakeholders and execution of strategic plans; although was statistically significant at alpha $=0.000$. Also, $R^{2}=0.056$ at significance level of 0.05 indicated that, $5.6 \%$ of the total variations in implementation of strategic plans is influenced by stakeholders and $94.4 \%$ is contributed by other factors which were not considered in this study. The study concluded that stakeholders do influence implementation of strategic plans in public sector.
\end{abstract}


In line with findings, the study recommended that management in public sector should pay more attention on stakeholders if they have to benefit from, otherwise may negatively influence implementation process of strategic plans in public sector.

Keywords: Tanzania, executive agencies, strategic plan, stakeholders, implementation

\section{Introduction}

Stakeholders are very crucial in the strategic management process (Mathur, Price \& Ali, 2008). So, when stakeholders are excluded, the relevance and anticipated benefits from the strategy will be limited. Also, the benefits accrued by organizations in defining stakeholders include impression management, relationship maintenance, and organisation goodwill (Hitt, Freeman and Harrison, 2001). Further, involving stakeholders expands firm's ability to develop collaborative relationships with a wide variety of economic and non-economic partners to find solutions (Sharma \& Starik, 2004). Moreover, Johnson and Scholes (2002) argues that the issue of stakeholders comes due to the increasing competition which makes almost impossible for any firm to accomplish all its business on its own; this leads to the need of managing the diverse interests of stakeholders to achieve organisation objectives successfully. In this regard, the organisational environment comprises both internal and external stakeholders (Pearce \& Robinson, 2009); where stakeholders from internal environment include directors and employees, while external stakeholders include government, the parent ministry, customers, suppliers, communities in general, the local community, trade unions, and activists; which in one way or another are involved in the execution of a strategic plan. However, given the importance of stakeholders in strategic plans implementation from different scholars (Abok, Gakure, Waititu, \& Ragui, 2013; Mathur et al, 2008; and Sharma \& Starik, 2004, Hitt et al, 2001; Johnson \& Scholes, 2002) no study established the impact of stakeholders on implementation of strategic plans in Tanzania's public sector. Therefore, this study bridged this literature gap and established the importance of stakeholders on implementation of strategic plans in Tanzania's public sector.

Strategy execution entails all activities and choices carried out to achieve organization objectives. It is through strategic implementations that policies and strategies are put into action via budgets, programs, and procedures (Wheelen \& Hunger, 2000). The execution of strategies includes a system-wide approach that guides the firm in the efficient and effective utilization of resources (Morgan, Levitt \& Malek (2007). That approach helps to devise, identify and prioritise the investments of the needed project in such a way everyone understands what is supposed to be done to implement the strategy. Implementation strategies successfully is a significant for any firm's survival in all sectors while formulating consistent and stable strategy is a difficult task but making that strategy implementable in the entire organisation is even more challenging and difficult (Hrebiniak, 2006). Therefore, failure in implementation process has caused many firm to find difficult to sustain competitiveness though with robust formulation process (Rajasekar, 2014); and hence ultimately threaten the survival of any organisation. 


\section{Literature Review}

Public sector encompasses organisational arrangements, political choices, community interests and objectives of organisation that are sometimes are at odds with those of stakeholders (Morgan et al, 2007). In public sector, both internal and external stakeholders are categorized with respect to the market, political, social, economic, legal and technological environments given the nature of their relationship to the firm, and how they influence the success or failure of a given strategy (Hrebiniak, 2009). It is to be noted that, stakeholders are very important and influential for the organisation success; whether for past, present or future operations of the firm or the environment surrounding the organisation (Pearce \& Robinson, 2009). Moreover, different stakeholders with different needs, demands and anticipations; will also have different views of what programme the firm should undertake or achieve (Hrebiniak, 2009). In this study, stakeholders such as politicians and government are difficult to avoid given their importance towards successful implementation of strategic plans in Tanzania's public sector and particularly executive agencies. Therefore, the components in respect to stakeholders which were considered in this study include stakeholder's contributions, interests, conflicting opinion, government policy and their responsibilities towards execution of strategies.

\subsection{Stakeholder's Theory}

Stakeholder theory states that every individual or group participate in the activities of organization in order to obtain benefits, and their priority of interests is not self-evident (Johnson, Scholes \& Whittington, 2008). Hence, interests define stakeholders' attachment to the organisation and all interests of stakeholders are intrinsically valuable. The theory recommends structures, practices and attitudes that require concurrent attentiveness to the interests of all genuine stakeholders. Also, stakeholders are considered as influential groups or individuals who have key interest in the actions of the firm by revisiting the past, present and future operations as well as environment surrounding the firm (Pearce \& Robinson, 2009). Also, corporate governance provides importance of understanding expectations of stakeholder and their differences from each other; as well as their influence over firm's strategies and purposes (Johnson et al., 2008). This study intends to focus specifically on this important area of the role of stakeholders in the success or failure of implementation of strategic plans of government executive agencies. Therefore, stakeholders have different interests in the organisations towards achieving organisation objectives, as well as towards implementation process of strategic plans, and this theory was relevant to the research hypothesis of this study:

\section{$H_{a}:$ Stakeholders' influences implementation of strategic plans in Tanzania's public sector}

\subsection{Conceptual Framework}

The conceptual framework of any study is a theory in a form of diagram that attempt to link and show variables relationship under study (Mugenda \& Mugenda, 2003). In this study, it was under assumption that while other things remain constant, implementation of strategic plans was theorized as dependent variable to roles of stakeholders. That is, independent 
variable positively or negatively affects implementation of strategic plan in public sector. The figure 2.1 shows the conceptual framework and how the variables were operationalized in this study.

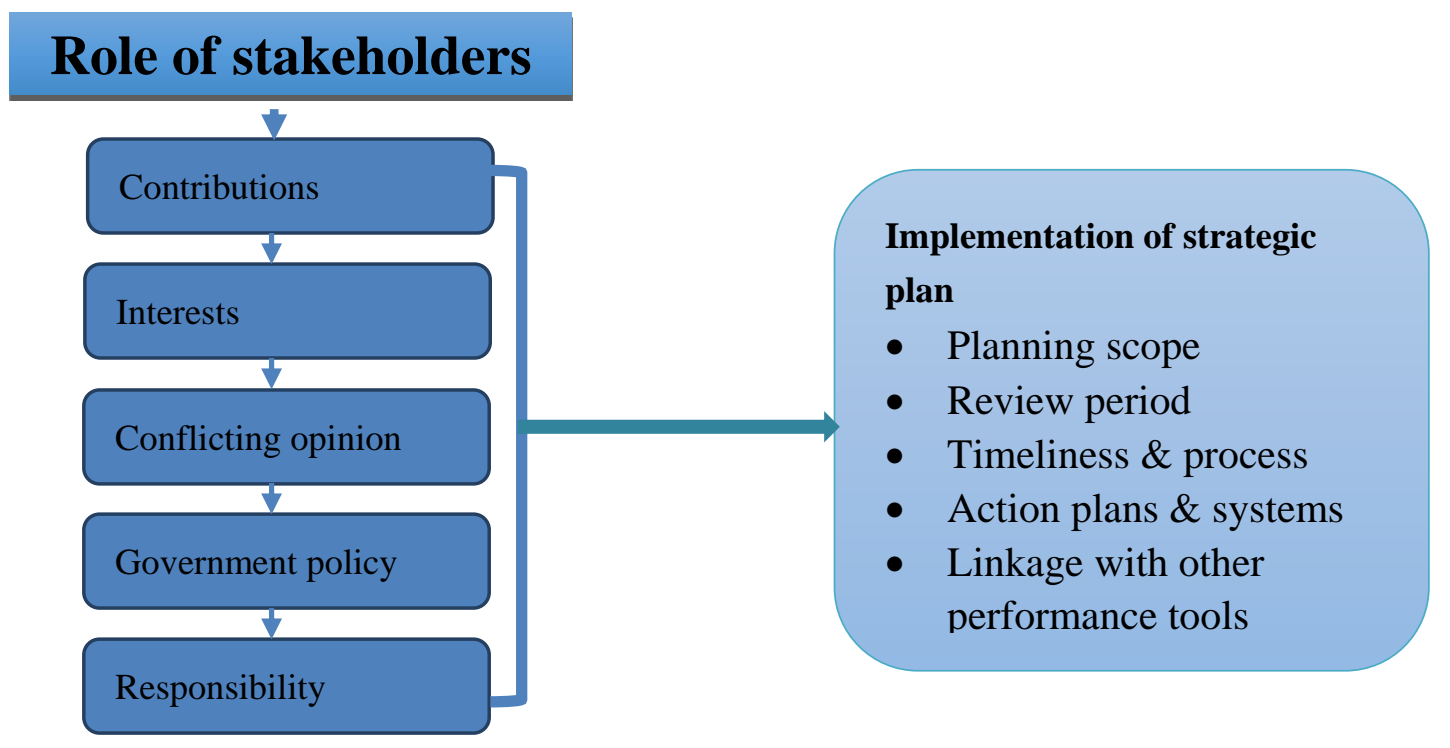

Figure 2.1. Conceptual framework of the study

\subsection{Empirical Review on Stakeholders}

Gedi and Muturi (2016) in the study on "Influence of Communication on Stakeholders Strategy Implementation in Garissa County, Kenya" found that, communication to stakeholders did not significantly influence strategy implementation and recommended that Garissa County government should plan for communication and public relations and have a budget for that. This has a similar but not identical focus to the current study, which focuses on the role of stakeholders in implementation. However, it is relevant in terms of identifying that channels of communication with stakeholders may be inadequate, and this may work in both directions. In addition, Dietz and Stern (2008), argued that, stakeholder involvement gives a way of securing consent from the governed in a clearer way and can avoid or reduce litigations and oppositional confrontations. The deeper public relationships which are based on reliable opportunities for meeting and concern sharing are likely to build credibility and trust to facilitate implementation of policy and revising processes. Finally, participatory processes need to foster a shared understanding of a problem and if involved participants feel empowered to contribute to the same level (Friedman, 2007).

\section{Methodology}

A descriptive survey design was adopted to collect information from different executive agencies in Tanzania. This design allows information collection, summarizing, interpretation and presentation of data (Orodho, 2009). The design was selected due to its ability to warranty impartiality (objectivity) and reliability of evidence from collected data. The target population of this study included employees working at headquarters of selected seven (7) 
executive agencies. Employees working in other offices rather than headquarters of selected agencies were not considered in this study. Both a probability and non-probability sampling technique were used, where probability sampling (simple random sampling) was used in selecting seven (7) out of twenty-seven (27) executive agencies; stratified random sampling was used to select 188 respondents from target population of 632 employees in headquarters of selected seven (7) executive agencies; directors and senior officials were selected using purposive sampling. Also, questionnaires, interviews and documentary review were tools used to collect both qualitative and quantitative data. A multiple regression model was useful to establish how independent variables (stakeholders) influence implementation of strategic plans in public sector where the significance level being $5 \%$.

\section{Results}

In this study, the data were collected from seven (7) Executive Agencies which is $26 \%$ from twenty-seven (27) agencies in Tanzania. Table 4.1 gives the details of the agencies which were sampled and the response rate of respondents in this study. The sample size of $26 \%$ is large enough as statistical inferences are valid at $10 \%$ of the population under a given study (Sekaran, 2010; Sounders, Lewis \& Thornhill, 2012; Kothari, 2011). Also, the study targeted 632 employees working at the headquarters of the seven executive agencies with expected sample size of 188 respondents out of which only 146 respondents returned the questionnaires, translating to $77.7 \%$ of the response rate. This is appropriate response rate as argued by Sekaran (2010) that, any response above $75 \%$ is classified as best to provide reliable information. Also, this is higher response rate compared to previous scholars such as Cater and Pucko (2010) had a response rate of 49\%, Awino (2007) had a response rate of 57\% and Abok et al (2013) had a response rate of $55 \%$ respectively from the target population of their study. This is further supported by Mugenda and Mugenda (2003) who supports that, any response rate with $50 \%$ is sufficient, $60 \%$ is good and $70 \%$ and above is excellent. Therefore, it is clear that the response rate of this study is excellent to provide reliable information.

Table 4.1. Response Rate

\begin{tabular}{lcccc}
\hline Agency & $\begin{array}{c}\text { Expected } \\
\text { Sample }\end{array}$ & $\begin{array}{c}\text { Observed } \\
\text { Frequency }\end{array}$ & $\begin{array}{c}\text { Percentage of the } \\
\text { Field Total }\end{array}$ & $\begin{array}{c}\text { Percentage within the } \\
\text { Agency }\end{array}$ \\
\hline TAESA & 21 & 18 & 12.3 & 85.7 \\
GPSA & 31 & 22 & 15.1 & 71 \\
TFSA & 29 & 16 & 11 & 55.2 \\
TEMESA & 33 & 27 & 18.5 & 81.8 \\
RITA & 26 & 24 & 16.4 & 92.3 \\
BRELA & 18 & 11 & 7.5 & 61.1 \\
GCLA & 30 & 28 & 19.2 & 93.3 \\
Total & $\mathbf{1 8 8}$ & $\mathbf{1 4 6}$ & $\mathbf{1 0 0}$ & $\mathbf{7 7 . 7}$ \\
\hline
\end{tabular}

\subsection{Role of Stakeholders}

This section investigated the role of stakeholders on influencing implementation of strategic plans in public sector. The respondents were given categorical questions to answer yes or no to the main question which asked, "are there roles played by stakeholders in implementation of strategic plans in public sector?" The results in figure 4.1 indicates out of 146 respondents, majority about 53\% recognized the role of stakeholders on influencing 
execution of strategies in executive agencies while $47 \%$ did not see any influence stakeholders in the operations of their respective organisations. The finding affirmed that stakeholders have vital influence on implementation of strategic plans in Tanzania's public sector.

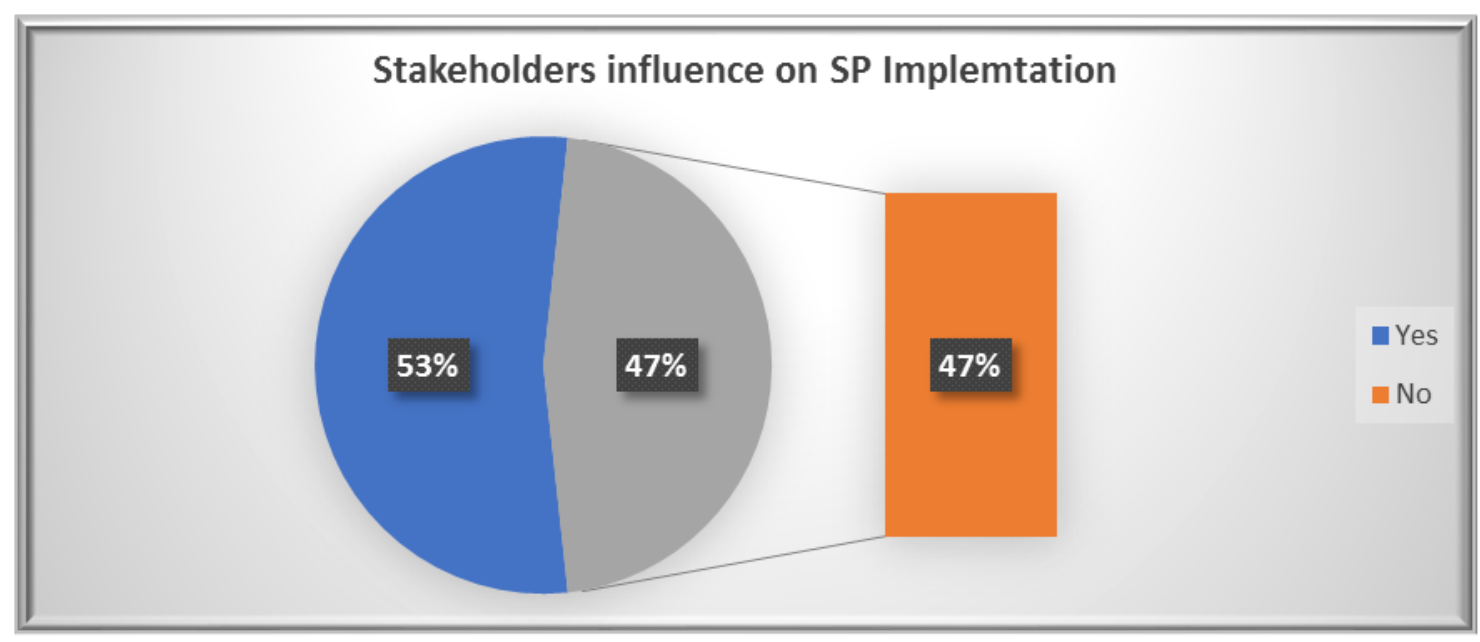

Figure 4.1. Stakeholders Influence on SP Implementation

Also, the following agencies ((Tanzania Electrical, Mechanical \& Electronics Services Agency-TEMESA, Government Procurement Services Agency - GPSA, Tanzania Forest Service Agency - TFSA, Tanzania Employment Service Agency - TaESA, Business Registrations and Licensing Agency - BRELA, Registration Insolvency Trusteeship Agency RITA \& Government Chemist Laboratory Agency - GCLA) recognized the role $\mathrm{f}$ stakeholders by pointing out the following contributions:

"RITA received (under five Birth Registration Initiative) and registration in camps from UNICEF, Birth Registration System Fourth Generation (BRS4G) from World Bank, while TFSA received support from World Wildlife Fund (WWF), Germany International Organisation (GIZ) and government of Tanzania in their various forest conservation initiatives, TEMESA has a sole right to maintain government owned vehicles, electrical and electronic projects, and usage of ferry services in the entire country, GCLA received DNA database support from government support, GPSA receive regulatory support from government regulators and use of integrated payment system through Bank of Tanzania (BOT), TaESA receive Capacity building support from GIZ" (Interviews, 20 ${ }^{\text {th }}$ June to $18^{\text {th }}$ July 2017).

Also, the question regarding the challenges, respondents were asked to mention challenges from stakeholders which can affect implementation of strategic plans in public sector while carrying day to day activities in their organisations. The following agencies (TEMESA, GPSA, TFSA, TaESA, BRELA, RITA \& GCLA) mentioned the frequently challenges posed by stakeholders in executive agencies:

"Presence of corruption, changing needs and demand from public, changing government priorities, interference from politicians, technology affects needs of our 
clients, insufficient capital to meet the growing demands of our clients, shortage of suppliers, dishonest clients and suppliers, non-compliance to Public Procurement Act, late payment from government institutions we supply goods and services, delay delivery from our suppliers, TEMESA has long standing debts from Ministries, autonomous departments, agencies and Local government authorities" (Interviews, $20^{\text {th }}$ June to $18^{\text {th }}$ August 2017).

The results support opinion of other (Johnson, Scholes \& Whittington, 2008) who argues that role of stakeholders in implementation of strategic plans cannot be avoided or neglected. Other scholars observed that stakeholders are always trying to influence strategies and purpose of organisations (Wambui, 2006).

Moreover, five point Likert scale was used to study five sub-variables of role of stakeholders which included: (a) contributions of stakeholders, (b) varying interests, (c) conflicting opinions, (d) government policy and (e) responsibilities of stakeholders on implementation process of strategic plans in Tanzania's public sector focusing on executive agencies. The questions in relation to these sub-variables required respondents to choose the following options:

$1=$ strongly disagree, $2=$ disagree, $3=$ neutral, $4=$ agree and $5=$ strongly agree

\subsection{Contributions of Stakeholders}

In respect to contributions of stakeholders, the first question investigated whether parent ministry support executive agencies operations in term of policy, rules and regulations in the process of implementation of strategic plans in Tanzania's public sector. The results in table 4.2 indicates out of 146 respondents, the majority about $50.1 \%$ agreed and $30.0 \%$ strongly agreed while $13.0 \%$ were neutral. The rest about $4.1 \%$ of respondents disagreed and few remaining about $1.4 \%$ strongly disagreed in respect to that opinion. Also, on the question as to whether donors support various projects in executive agencies in the process of implementing their strategic plans and business plans, the findings in figure 4.2 revealed that majority of respondents about $38 \%$ were neutral while $29 \%$ and $14 \%$ of respondents agreed and strongly agreed respectively. The balance of $15 \%$ and $4 \%$ of respondents disagreed and strongly disagreed respectively. 


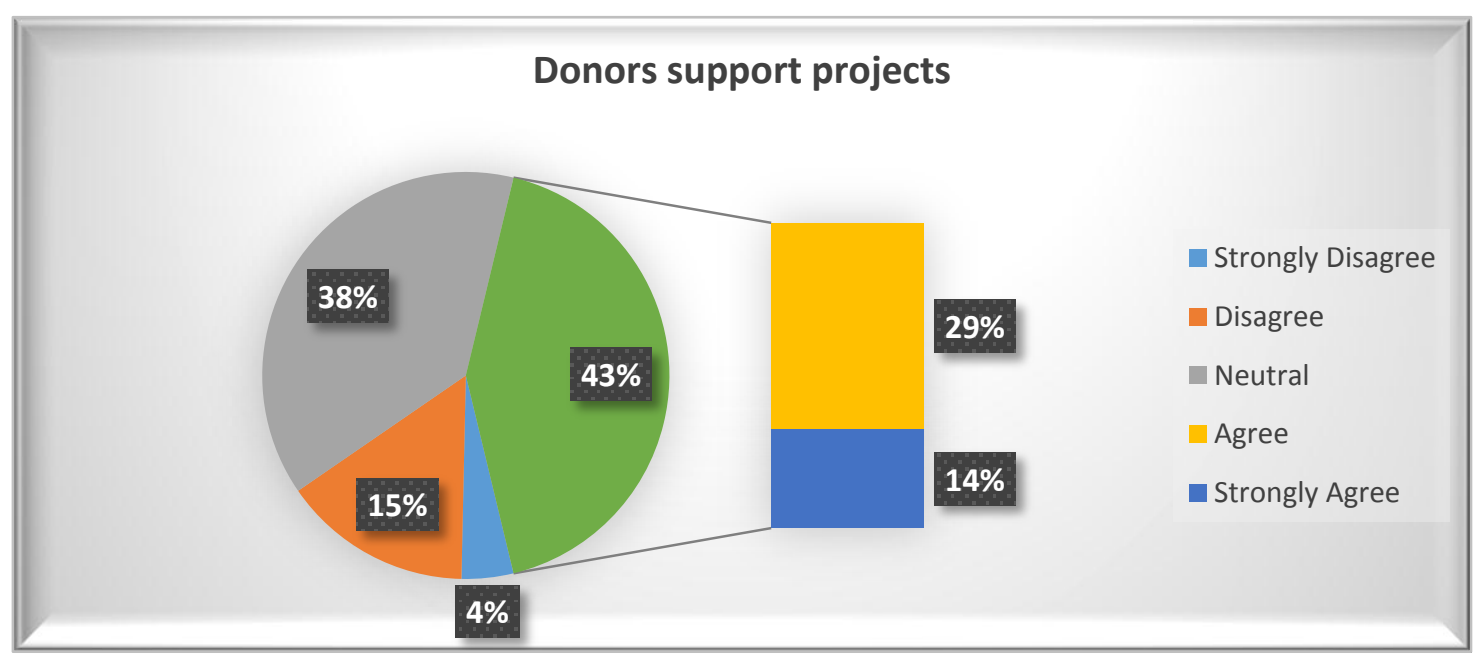

Figure 4.2. Donors Support Projects

Further, the question as to whether executive agencies receive contributions and other support from various stakeholders to enable successful execution of strategies in Tanzania's public sector. The findings in table 4.2 indicates out of 146 respondents, the majority about $39.7 \%$ agreed and $10.3 \%$ strongly agreed while $26.7 \%$ were neutral. The rest about $16.4 \%$ disagreed and very few about $6.8 \%$ strongly disagreed. Furthermore, the mean average of 3.3 and standard deviation of 1 implies that the majority of respondents were neutral on the contributions of stakeholders on fostering implementation of strategic plans in public sector. These finding correlates with Johnson et al. (2008) who argues that stakeholders can negatively or positively contribute to the organisation depending on their orientation (internal or external), while other scholars are not clear whether stakeholders contribute or not to the organisation performance (Mulube, 2009). Therefore, the majority of respondents were neutral on the contributions of stakeholders on fostering implementation of strategic plans in public sector. The study concludes that, most of respondents are not aware of support from parent ministries, donors and other stakeholders towards implementation of strategic plans in Tanzania's public sector.

\subsection{Varying Interests of Stakeholders}

Regarding varying interests of stakeholders, the first question investigated whether parent ministries interfere executive agencies plans which affects their operations in the process on implementing strategic plans in public sector. The results in figure 4.3 indicates out of 146 respondents, the majority about $36 \%$ were neutral while $14 \%$ agreed and $6 \%$ strongly agreed in respect to that opinion. The remaining balance $30 \%$ and $6 \%$ of respondents disagreed and strongly disagreed respectively. Further, on the question whether stakeholders support executive agencies interests despite diversified interests in process of executing strategic plans in Tanzania's public sector. The findings in the table 4.2 indicates out of 146 respondents, the majority about $47.9 \%$ were neutral while $34.2 \%$ agreed and $5.5 \%$ strongly agreed in respect to that opinion. The rest about $11.6 \%$ of respondents disagreed and few about $0.7 \%$ strongly disagreed respectively. 


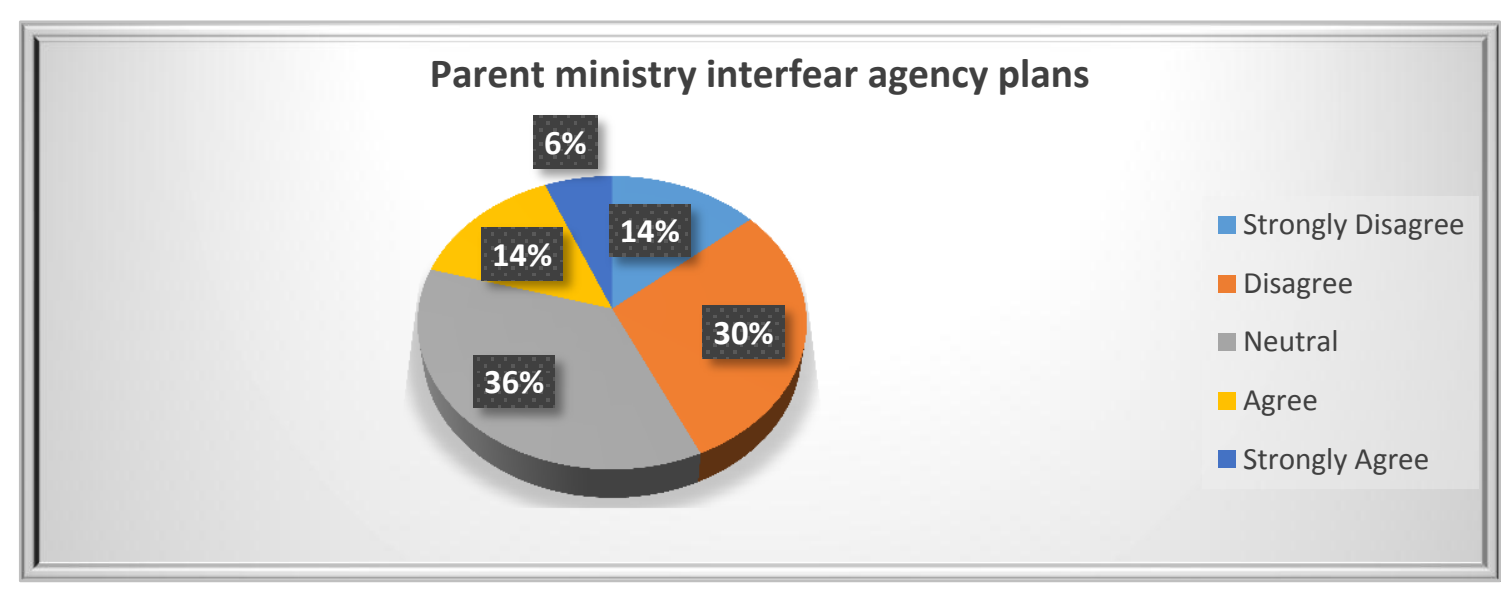

Figure 4.3. Parent Ministry Interfere Agency Plans

Furthermore, the question as to whether organisation's interests are highly prioritized over stakeholders or individuals interests in Tanzania's executive agencies. The results in table 4.2 indicates out of 146 respondents, majority about $39.0 \%$ were neutral while $35.0 \%$ agreed and $9.6 \%$ strongly agreed. The balance of about $14.4 \%$ of respondents disagreed and rest $2.1 \%$ strongly disagreed on this opinion. Moreover, the mean average of 3 and standard deviation of 1 implies that the majority of respondents were neutral on varying interests of stakeholders on supporting implementation of strategic plans in Tanzania's executive agencies. The findings are in line with Arasa (2008) and Mulube (2009) who confirmed that stakeholders influence negatively implementation of strategies if their interest conflict or are against with those of an organisation. The study establishes that stakeholders support organisation interest only when their interests are contained. Therefore, the majority of respondents were neutral on varying interests of stakeholders on supporting implementation of strategic plans in Tanzania's executive agencies, and the study concludes that, most of respondents are not aware of ministries interference, diversifies interests from stakeholders, and prioritization of organisation interests towards implementation of strategic plans in Tanzania's public sector.

\subsection{Conflicting Opinion of Stakeholders}

In respect to confliction opinion of stakeholders, the first question investigated whether parent ministries demand conflicts with executive agencies objectives which hinder performance in the process of execution of strategic plans in public sector. The results in table 4.2 indicates out of 146 respondents, majority about $40.4 \%$ were neutral while $14.4 \%$ agreed and $7.5 \%$ strongly agreed. On the other hand, $27.4 \%$ disagreed and $103 \%$ strongly disagreed. Also, on the question as to whether politicians' opinions are not always positives towards achieving organisation objectives in the process of implementing strategic plans in public sector. The findings in figure 4.4 indicates out of 146 respondents, majority about $36 \%$ of respondents were neutral while $29 \%$ agreed and $7 \%$ strongly agreed in respect to that question. The rest $23 \%$ disagreed and $5 \%$ strongly disagreed respectively. 


\section{Il Macrothink}

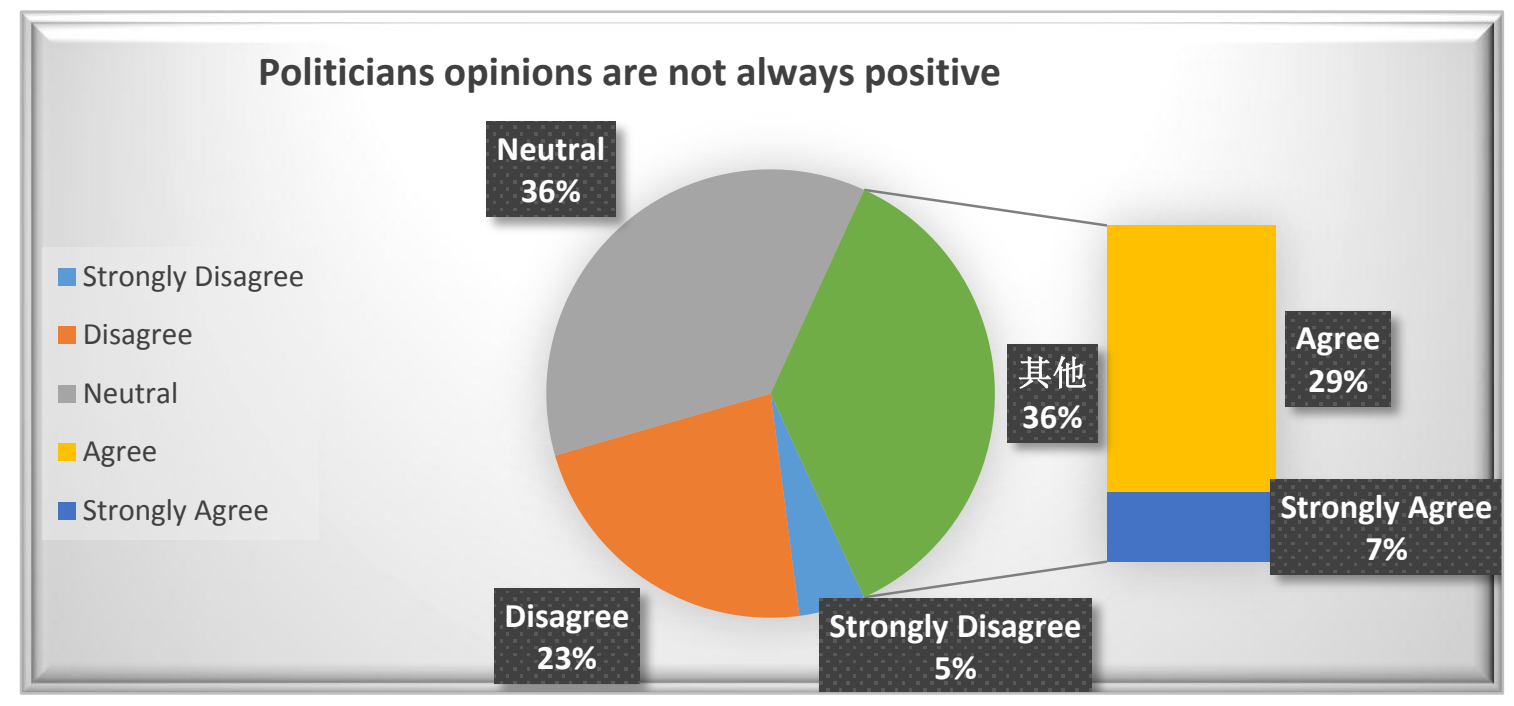

Figure 4.4. Politicians Opinions are not Always Positive

Further, on question as to whether public opinion may affect negatively agencies strategies towards achieving organisation objectives. The results in table 4.2 discloses out of 146 respondents, majority $40.4 \%$ were neutral while $32.2 \%$ agreed and $6.2 \%$ strongly agreed. The balance of respondents about $17.1 \%$ disagreed and $4.1 \%$ strongly disagreed in respect to this question. Moreover, the mean average of 3 and standard deviation of 1 implies that the majority of respondents were neutral in regard to confliction opinion of stakeholders such as parent ministry demand, politicians, and public interests in the process of implementing strategic plans in Tanzania's executive agencies. Therefore, the evidence adduced from the results above concludes that, the majority of respondents were neutral regarding to the parent ministry demand, politicians, and public interests in the process of implementing strategic plans in Tanzania's executive agencies, and hence the study affirms that, there is no clear contributions of stakeholders in Tanzania's public sector.

\subsection{Government Policy}

Regarding government policy, the first question investigated whether executive agencies operations are highly influenced by existing policies from parent ministries in the process of implementing strategic plans in public sector. The results in figure 4.5 indicates out of that, $49 \%$ agreed and $17 \%$ strongly agreed while $19 \%$ were neutral. The rest about $10 \%$ of respondents disagreed and 5\% strongly disagreed. 


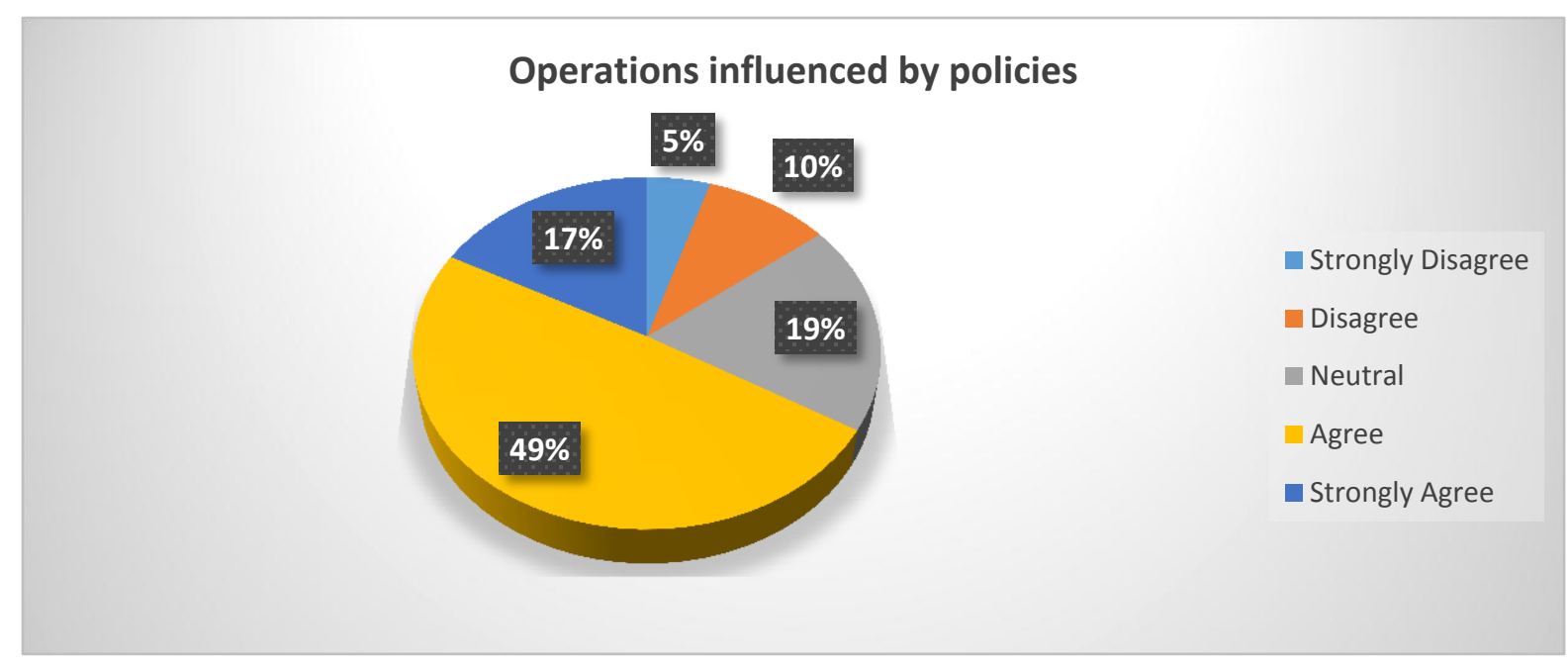

Figure 4.5. Operations Influenced by Policies for Parent Ministry

Also, on the question as to whether ah-hoc policies made by government influence agencies operations in the process of executing strategic plans in Tanzania's public sector. The results in table 4.2 indicates out of 146 respondents, majority about $42.5 \%$ were neutral while $34.9 \%$ agreed and $10.3 \%$ strongly agreed. On the other hand, $7.5 \%$ and $4.8 \%$ of respondents disagreed and strongly disagreed on that respective question. This is further supported by one Director at GCLA Headquarter who claimed that:

"we were directed by Prime Minister to investigate and analyze deoxyribonucleic acid (DNA) for Faru John which died and raised controversial issues as probably the black rhino was sold out of the country. We were directed to go and undertake DNA if the wild animal indeed died. We finally established that the beast died while being nursed at private Sasakwa Grumeti Reserve, the activity which consumed lot of money and was not in our plans" (Interview, 25 ${ }^{\text {th }}$ July 2017).

Note: Faru John was the name given to one of the black rhinos imported in Tanzania from South Africa.

Furthermore, on the question as to whether organisations frequently change their operations to reflect changes in government policies while implementing strategic plans. The results in table 4.2 indicates out of 146 respondents, majority about $41.8 \%$ were neutral while $29.5 \%$ agreed and $12.3 \%$ strongly agreed. The balance about $13.7 \%$ of respondents disagreed and $2.7 \%$ strongly disagreed. Moreover, the mean average of 3.7 and standard deviation $=1$ indicates that, the majority of respondents agreed on negative influence of government policies towards implementation of strategic plans in public sector. The findings are supported by other scholars such as Salamon (2002) who argues that the government tools can directly or indirectly influence performance of organisations. The result confirms that executive agencies in Tanzania are negatively affected by government policies toward implementing their strategic plans, this translates into unplanned projects from the central governments and parent ministries which negatively affect planned priorities in the existing strategic plans. 


\subsection{Responsiveness of Stakeholders}

In respect to responsibility of stakeholders, the first question investigated as to whether the government and public are supportive to the business operations of the organisations in the process of implementing strategic plans in public sector. The result in table 4.2 indicates out of 146 respondents, majority about $51.4 \%$ agreed and $19.9 \%$ strongly agreed while $22.6 \%$ were neutral. The rest $4.8 \%$ disagreed and $1.4 \%$ strongly disagreed. Also, on the question as to whether there are committed donors and other stakeholders who support implementation of strategic plans in Tanzania's public sector. The result in table 4.2 indicates out of 146 respondents, the majority about $43.9 \%$ were neutral while $28.1 \%$ agreed and $8.2 \%$ strongly agreed. On the other hand, $23.3 \%$ disagreed and $5.5 \%$ strongly disagreed on that respective opinion.

Further, on the question as to whether agencies stakeholders respond positively to moral and material support towards achieving organisation objectives in public sector. The result in figure 4.6 indicates out of 146 respondents, majority about $43 \%$ agreed and $7 \%$ strongly agreed while $35 \%$ were neutral. The balance about $12 \%$ and $3 \%$ disagreed and strongly disagreed respectively. Furthermore, the mean average of 3.3 and SD $=1$ suggests that the majority were neutral on the responsiveness of stakeholders towards implementation of strategic plans in public sector.

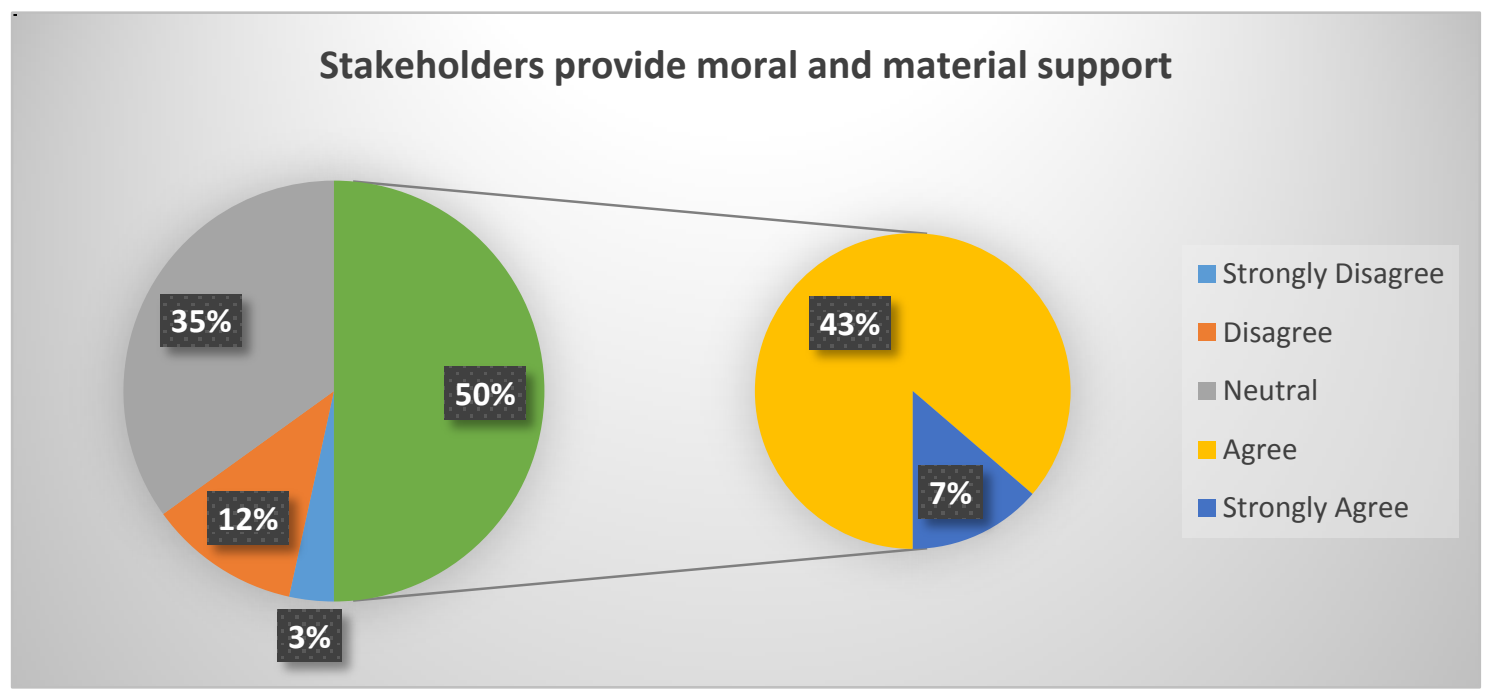

Figure 4.6. Stakeholders provide moral and material support

The result supports Johnson et al. (2008) who affirmed that stakeholders' orientation can shows positive and negative support in respect to whether are external or internal stakeholders. This was supported by other scholars regarding stakeholders clear support or lack of support (Mulube, 2009; Abok et al, 2013). The result of this study confirms that Tanzania's executive agencies are affected in way or another by actions of stakeholders such as government, donors, politicians and public while implementing their strategic plans. Therefore, the result confirms that, the majority were neutral on the responsiveness of stakeholders towards implementation of strategic plans in public sector. The study concludes that, respondents are not aware of support from donors, government and public towards 
successful implementation of strategic plans in Tanzania's public sector.

Table 4.2. Respondent's Opinion on Roles of Stakeholders

\section{Statement/Item}
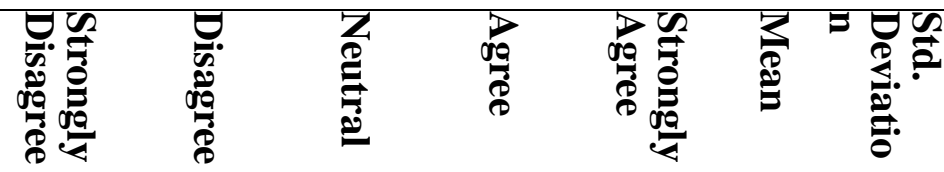

Parent ministry support org operations in term of policy, roles and regulations Donors support various projects in our organisation

\begin{tabular}{lllllll}
$1.4 \%$ & $4.1 \%$ & $13.0 \%$ & $50.7 \%$ & $30.0 \%$ & 4 & 1 \\
$4.1 \%$ & $15.1 \%$ & $38.4 \%$ & $28.8 \%$ & $13.7 \%$ & 3 & 1 \\
$6.8 \%$ & $16.4 \%$ & $26.7 \%$ & $39.7 \%$ & $10.3 \%$ & 3 & 1 \\
$13.7 \%$ & $29.5 \%$ & $36.3 \%$ & $14.4 \%$ & $6.2 \%$ & 3 & 1 \\
$0.7 \%$ & $11.6 \%$ & $47.9 \%$ & $34.2 \%$ & $5.5 \%$ & 3 & 1 \\
$2.1 \%$ & $14.4 \%$ & $37.0 \%$ & $37.0 \%$ & $9.6 \%$ & 3 & 1 \\
$10.3 \%$ & $27.4 \%$ & $40.4 \%$ & $14.4 \%$ & $7.5 \%$ & 3 & 1 \\
$4.1 \%$ & $17.1 \%$ & $40.4 \%$ & $32.2 \%$ & $6.2 \%$ & 3 & 1 \\
$4.8 \%$ & $7.5 \%$ & $42.5 \%$ & $34.9 \%$ & $10.3 \%$ & 3 & 1 \\
$2.7 \%$ & $13.7 \%$ & $41.8 \%$ & $29.5 \%$ & $12.3 \%$ & 4 & 1 \\
\hline $1.4 \%$ & $4.8 \%$ & $22.6 \%$ & $51.4 \%$ & $19.9 \%$ & 4 & 1 \\
$5.5 \%$ & $23.3 \%$ & $34.9 \%$ & $28.1 \%$ & $8.2 \%$ & 3 & 1 \\
\hline
\end{tabular}

Organisation receives contributions and other support from various stakeholders Parent Ministry interfere our plans which affect org operations

Stakeholders support Organisation Interests despite diversified interests Organisation interests are prioritized over stakeholders/individual interests Parent ministry demand may conflict organisation objectives

Public opinion may affect negatively our strategies towards achieving organisation objectives

Ad-hoc policies made by government influence org operations

Organisation frequently change its operations to reflect changes in government policies

Government and public are supportive to the business operations

There are committed donors and other stakeholders to the operations of our org

\subsection{Correlation Analysis}

The findings in the table 4.3 indicates the Pearson correlation of role of stakeholders on implementation of strategic plans. $\mathrm{R}$ is 0.236 at 0.05 level of significance. This implies that there was a weak positive linear correlation between role of stakeholders and implementation of strategic plans in Tanzania's public sector.

Table 4.3. Correlations of Role of Stakeholders and SP implementation

\begin{tabular}{llcc}
\hline & & $\begin{array}{l}\text { Implementation } \\
\text { of SP }\end{array}$ & Role of Stakeholders \\
\hline Implementation of & Pearson Correlation & 1 & $.236^{* \pi}$ \\
Strategic Plan & Sig. (2-tailed) & & .004 \\
& $\mathrm{~N}$ & 146 & 146 \\
& Pearson Correlation & $.236^{\cdots \cdots}$ & 1 \\
Role of Stakeholders & Sig. (2-tailed) & .004 & 146 \\
& $\mathrm{~N}$ & 146 & 146 \\
\hline
\end{tabular}

***Correlation is significant at the 0.01 level (2-tailed). 


\subsection{Regression Analysis on Role of Stakeholders}

In respect to role of stakeholders, the study sought to establish the relationship between role of stakeholders and implementation of strategic plans in Tanzania's public sector. The null hypothesis of studying this variable was: $H_{0}$ : There is no significance relationship between role of stakeholders and implementation of strategic plans; at significance level of $5 \%$.

Table 4.4. Model Summary for Role of Stakeholders

\begin{tabular}{ccccc}
\hline Model & R & R Square & Adjusted R Square & Std. Error of the Estimate \\
\hline & $.236^{\mathrm{a}}$ & .056 & .049 & 7.557 \\
\hline
\end{tabular}

a. Predictors: (Constant), Role of Stakeholders

Also, in Table 4.4 in respect to coefficient of determination $\left(R^{2}\right)$ is 0.056 which indicates that $5.6 \%$ of the variations in implementation of strategic plans is influenced by role of stakeholders. This implies that, only $5.6 \%$ is contributed by stakeholders while $94.4 \%$ is contributed by other factors towards successful implementation of strategic plans in Tanzania's executive agencies. The R-square agrees with what were obtained by Namubiru (2014) which were low ranging from $5 \%$ to $17 \%$ and concluded that low $R^{2}$ are common in studies involving cross- sectional data and large in time series data.

Table 4.5. Analysis of Variance (ANOVAa) for Role of Stakeholders

\begin{tabular}{lccccc}
\hline Model & $\begin{array}{c}\text { Sum of } \\
\text { Squares }\end{array}$ & df & Mean Square & F & Sig. \\
\hline Regression & 485.225 & 1 & 485.225 & 8.496 & $.004^{\text {D }}$ \\
Residual & 8224.145 & 144 & 57.112 & & \\
Total & 8709.370 & 145 & & & \\
\hline
\end{tabular}

a. Dependent Variable: Implementation of SP

b. Predictors: (Constant), Role of Stakeholders

Further, the analysis of variance (ANOVA) results as indicated in table 4.5 confirms that, the model goodness of fit is appropriate for this data since $\mathrm{F}=8.496$ and p-value of 0.004 which is less than significance level of 0.05 . Hence, we reject the null hypothesis and conclude that there is a significant linear relationship between role of stakeholders and implementation of strategic plans in Tanzania's executive agencies.

Table 4.6. Coefficientsa of Role of Stakeholders and Implementation of SP

\begin{tabular}{lcccccc}
\hline Model & & \multicolumn{2}{c}{ Unstandardized } & Standardized & $\mathrm{t}$ & Sig. \\
& & \multicolumn{2}{c}{ Coefficients } & Coefficients & & \\
& $\mathrm{B}$ & Std. Error & Beta & & \\
\hline (Constant) & 48.580 & 2.349 & & 20.684 & .000 \\
Role of Stakeholders & .123 & .042 & .236 & 2.915 & .004 \\
\hline
\end{tabular}

a. Dependent Variable: Implementation of SP

Moreover, the results revealed that role of stakeholders have positive and significant effects on implementation of strategic plans as indicated in Table 4.6. The model of goodness fit ISP 
$=48.580+0.123 \mathrm{X} 4+\varepsilon$. The model implies that a unit change in role of stakeholders will influence implementation of strategic plan by the rate of 0.123 holding other factors constant, and even if role of stakeholders is non-existence, implementation of strategic plans in executive agencies is still positive at a rate of 48.580. This shows that there are other factors such as top management support, organisation resources and organisation culture which can influence implementation process of strategic plans even if role of stakeholders is at a rate of zero in Tanzania's executive agencies.

\subsection{Role of Stakeholders on Implementation of Strategic Plans}

In respect to this objective the study sought to investigate the role of stakeholders' influence on implementation of strategic plans in public sector. The results indicated that, $53 \%$ of respondents recognized the role of stakeholders on execution of strategies in executive agencies while $47 \%$ did not see any influence stakeholders in the operations of their respective organisations. The results of this study are supported by other scholars such as Johnson et al. (2008) who argues that role of stakeholders in implementation of strategic plans cannot be avoided or neglected. Other scholars observed that stakeholders are always trying to influence strategies and purpose of organisations (Wambui, 2006). Further, the mean average of 3.3 and $\mathrm{SD}=1$ suggests that the majority were neutral on the contributions of stakeholders towards implementation of strategic plans in public sector. The result supports Johnson et al. (2008) who affirmed that stakeholders' orientation can shows positive and negative support in respect to whether are external or internal stakeholders. This was in line with other scholars regarding stakeholders clear support or lack of support (Mulube, 2009; Abok et al, 2013). The result of this study confirms that Tanzania's executive agencies are affected in one way or another by actions of stakeholders such as government, donors, development partners, politicians and public while implementing their strategic plans.

Furthermore, the study sought to establish the relationship between role of stakeholders and implementation of strategic plans in Tanzania's executive agencies. The Pearson correlation (R) is 0.236 at 0.05 level of significance. This implies that there is a weak positive relationship between role of stakeholders and implementation of strategic plans at significance level of 5\%. Also, coefficient of determination $\left(R^{2}\right)$ is 0.056 which indicates that $5.6 \%$ of the variations in implementation of strategic plans are influenced by role of stakeholders. This implies that, only $5.6 \%$ is contributed by stakeholders towards successful implementation of strategic plans in Tanzania's executive agencies. Moreover, the model of goodness fit of this variable is ISP $=48.580+0.123 \mathrm{X} 4+\varepsilon$. The model implies that a unit change in role of stakeholders will influence implementation of strategic plan by the rate of 0.123 holding other factors constant, and even if role of stakeholders is non-existence, implementation of strategic plans in executive agencies is still positive at a rate of 48.580 . This shows that there are other factors such as top management support, organisation resources and organisation culture which can influence implementation process of strategic plans even if role of stakeholders is at a rate of zero in Tanzania's executive agencies, though in real practice this can hardly happen. 


\section{Conclusion and Recommendation}

The study investigated the impact of stakeholders on implementations of strategic plans in public sector. The result confirmed that, the majority of respondents were neutral on the stakeholders' influence towards implementation of strategic plans in executive agencies. Also, the findings in regression coefficient revealed that, the variable has $t=5.742$ and $p$-value $=$ 0.000 which is less than significance level of 0.05 . This implied that, stakeholders do influences implementation of strategic plans in Tanzania's public sector. Therefore, the study concluded that, stakeholders do influence implementation of strategic plans in public sector.

Further, based on the findings the study recommends that, given the ad-hock nature of public policies and directive in Tanzania's public sector, the top management should prepare themselves for emergent plans in order to accommodate ad-hock programmes from central government and parent ministry without affecting their planned strategies. Liaison with government during formulation is the best option in order to know if there are new future initiatives which may affect their plans if not included.

\section{Areas for Further Study}

Moreover, due to the complex nature of public sector environment in Tanzania, a similar study should be conducted to pure civil service and local authorities in order to investigate whether there are any areas of commonalities or unique factors with executive agencies in Tanzania's public sector. Finally, the study findings established that role of stakeholders contribute only $5.6 \%$ of the variations in implementation of strategic plans. This implies that $94.4 \%$ is contributed by other variables not tested is this study. Therefore, factors such as organisation structure, management styles, monitoring and evaluations, and other related factors should be considered for further study to establish their contributions towards implementation of strategic plans in public sector.

\section{References}

Abok, A., Gakure, R., Waititu, A., \& Ragui, M. (2013). Culture's role in the implementation of strategic plans in non-governmental organizations in Kenya. Prime Journal of Social Science, 2(4), 291-295.

Arasa, R. M. (2008). The Challenges of Implementing Strategic Plans in Large Management Consultancies. University of Nairobi: Unpublished $\mathrm{PhD}$ thesis.

Awino, Z. B. (2007). The Effect of Selected Variables on Corporate Performance: A Survey of Supply Chain Management in Large Private Manufacturing Firms in Kenya. University of Nairobi: Unpublished report.

Cater, T., \& Pucko, D. (2010). Factors of Effective Strategy Implementation: Empirical Evidence from Slovenian Business Practice. Journal for East European Management Studies, 15(3), 207-236.

Dietz, S., \& Stern, N. (2008). Why Economic Analysis Supports Strong Action on Climate Change. Review of Environmental Economics and Policy, 8(2), 94-113. 
https://doi.org/10.1093/reep/ren001

Friedman, R. (2007). Managing for Stakeholders: Essential Readings in Ethical Leadership and Management. Amherst NY: Prometheus Books.

Gedi, A. M., \& Muturi, W. M. (2016). Influence of Communication on Stakeholders Strategy Implementation in Garissa County, Kenya, European Journal of Business and Social Sciences, $5(2), 152-159$.

Hitt, M., Freeman, R., \& Harrison, J. (2001). The Blackwell Handbook of Strategic Management. Hoboken, NJ: Wiley- Blackwell Publishers Ltd.

Hrebiak, L. G. (2006). Obstacles to Effective Strategy Implementation; Organisation Dynamics, 35(1), 12-31. https://doi.org/10.1016/j.orgdyn.2005.12.001

Johnson, G., \& Scholes, K. (2002). Exploring Corporate Strategy, 6th Edition, Pearson Education Limited, Essex.

Johnson, G., Scholes, K., \& Whittington, R. (2008). Exploring Corporate Strategy: Text and Cases. $7^{\text {th }}$ Ed.). New Delhi: Dorling Kindersley (India) Pvt. Ltd.

Johnson, L. K. (2004). Execute your strategy-without killing it. Harvard Management Update, 9(12), 3-6.

Kothari, C. R. (2011). Research Methodology: Methods and Techniques. (2 ${ }^{\text {nd }}$ Ed.). Revised New Age International (P) Limited Publishers, New Delhi.

Mathur, V., Price, A., \& Ali, S. (2008). Conceptualizing stakeholder engagement in the context of sustainability and its assessment. Journal of Construction Management and Economics, 26(6), 601-609. https://doi.org/10.1080/01446190802061233

Morgan, M., Levitt, R. E., \& Malek, W. (2007). Executing Your Strategy; How to Break It Down and Get It Done. USA: Harvard Business Publishing.

Mugenda, O. M., \& Mugenda, A. G. (2003). Research Methods: Quantitative and Qualitative Approaches. Nairobi: Acts Press.

Mulube, J. K. (2009). Effects of organizational culture and competitive strategy on the relationship between human resource management strategic orientation and firm performance. University of Nairobi: Unpublished PhD Thesis.

Orodho. J. A. (2009). Elements of Education and Social Science Research Methods. Nairobi; Kenya, Kanezja Publishers.

Pearce, J. A., \& Robinson, R. B. (2009). Strategic Management: Formulation, Implementation and Control, 7 Ed. Homewood, IL: Richard D. IRWIN Inc.

Rajasekar, J. (2014). Factors Affecting Effective Strategy Implementation in a Service Industry: A Study of Electricity Distribution Companies in the Sultanate of Oman. International Journal of Business and Social Science, Vol. 5, No. 9(1). 


\section{Macrothink}

Journal of Public Administration and Governance

ISSN 2161-7104 2017, Vol. 7, No. 4

Salamon, L. M. (2002). The Tools of Government. A guide to the new Governance, New York: Oxford University Press.

Saunders, M., Lewis, P., \& Thornhill, A. (2012). Research Methods for Business Students, $\left(6^{\text {th }}\right.$ Ed), Pearson Education Limited, Edinburgh Gate, Harlow.

Sekaran, U. (2010). Research Methods for Business: A Skill Building Approach. $\left(5^{\text {th }}\right.$ ed). USA: John Wiley \& Sons Publisher.

Sharma, S., \& Starik, M. (2004). Stakeholders, the Environment and Society. Cheltenham: Edward Elgar. https://doi.org/10.4337/9781845423629

Wambui, G. L. (2006). Managers and Strategy Implementation in NGOs. University of Nairobi: Unpublished Report.

Wheelen, T. L., \& Hunger, J. D. (2000). Strategic Management and Business Policy. Entering 21 st Century Global Society. Addison Wesley Longman, Inc.

\section{Copyright Disclaimer}

Copyright for this article is retained by the author(s), with first publication rights granted to the journal.

This is an open-access article distributed under the terms and conditions of the Creative Commons Attribution license (http://creativecommons.org/licenses/by/4.0/). 